\title{
Forensic Evidence: Materializing Bodies, Materializing Crimes ${ }^{1}$
}

\section{Corinna Kruse}

\begin{abstract}
Based on an ethnographic study of fingerprint and DNA evidence practices in the Swedish judicial system, this article analyzes the materialization of forensic evidence. It argues that forensic evidence, while popularly understood as firmly rooted in materiality, is inseparably technoscientific and cultural. Its roots in the material world are entangled threads of matter, technoscience, and culture that produce particular bodily constellations within and together with a particular sociocultural context. Forensic evidence, it argues further, is co-materialized with crimes as well as with particular bodily and social constellations. Consequently, the article suggests that an analysis of how forensic evidence is produced can contribute to feminist understandings of the inseparability of sex and gender: understanding bodies as ongoing technoscientific-materialcultural practices of materialization may be a fruitful approach to analysing their complexity, and the relationships in which they are placed, without surrendering to either cultural or biological determinism.
\end{abstract}

KEY WORDS: materialization, bodies, forensic evidence, agential realism, technoscience, meaning, matter

Taking forensic evidence as its point of departure, this article aims to contribute to discussions of materiality, especially the body's materiality. I intend to propel practices of producing ${ }^{2}$ forensic evidence, so far predominantly discussed within science and technology studies (STS), into the arena of material feminism. As Ruth Hubbard argues, 'science has had a significant part in the making of women' (Hubbard, 1990: 17) through defining 'normal' bodies. I aim to discuss, using the example of forensic evidence, how technoscience makes bodies. I want to bring STS's focus on everyday technoscientific practices of producing knowledge into conversation with material feminism's focus on sexed embodiment. Analysing the production of forensic evidence, I maintain, can contribute to understanding how sex (and sexed bodies) are materialized as inextricably material-discursive.

Forensic science, and the evidence it delivers to the criminal justice system, is receiving keen interest from media and popular cultures, where a prevailing theme seems to be the reliability with which forensic science can connect suspect bodies to crime scenes. Scholarly interest tends to focus on issues of risk (McCartney, 2006), expertise and expert systems (for example, Bal, 2005; Cole, 2001; Haack, 2003; Halfon, 1998; Lynch et al, 2008; Prainsack and Kitzberger, 2009) and civil liberties and ethics (Noble, 2006; Rothstein and Talbott, 2006). There seems to be a common focus on - and sometimes concern for - the solidity that forensic evidence is perceived to possess. It seems to be understood as firmly rooted in the material world and thus more tangible and reliable than, for example, witness testimony.

This article will examine forensic evidence's affiliation with materiality, analysing the connection between the crime scene and the suspect body that it produces. It draws on 
ethnographic material from the Swedish judicial system. I have interviewed and followed crime scene officers, forensic laboratory staff, police detectives, and prosecutors working with forensic evidence. As all ethnographic material, the data collected in this study is local, contingent on particular circumstances and a particular judicial system. However, the questions and thoughts that can be raised based on this local material are relevant in a wider context.

Through fingerprint and DNA evidence, I will argue that, rather than making use of the body's materiality, forensic science, together with law enforcement and legal practices, materializes the (criminal) body at the same time as it establishes the connection between a particular body and a particular crime scene. Consequently, I will argue, materiality is an activity rather than an intrinsic quality. More than that, it is an activity that involves not only matter but also technology, as well as both technoscientific and other cultural practices, resulting in forensic evidence that is inseparably material, technological, and cultural. I will argue that bodies can be understood as continuously materialized through material-technoscientific-cultural practices, comaterialized with subject positions and social contexts.

Through my analysis of materializing bodies in forensics, I shall suggest that current feminist materialist endeavours to conceptualize sexed embodiment as non-deterministic processes, could be enriched by reflecting on analogies to the material-technoscientific-cultural practices involved in the production of forensic evidence. Taking my theoretical point of departure not only in an STS-informed approach, but also in material feminist theorizations (Butler 1993, Grosz 1994, Barad 1996, 1998, 2007, Birke 1999, Alaimo and Hekman 2002), I shall, moreover, underline that the theoretical conversations across borders of feminist theory and STS that I suggest here, should be understood as a two-way-communication where the two fields contribute mutually to each other.

\section{Thinking about bodies}

Feminist discussions of the body often point to how biological bodies have been used as a justification for social and cultural ordering, for example through

'the fragility, unreliability, or biological closeness to nature attributed to the female body and the subordinate character attributed to women on account of the close connections between female psychology and biology. Women have been objectified and alienated as social subjects partly through the denigration and containment of the female body' (Grosz, 1994: xiv).

In other words, bodies - ostensibly imperturbable 'facts' of 'nature' - are being set in direct correlation to social relationships, be they between sexes, classes, or races. Hence, it is not surprising that discussions of materiality have been avoided as carrying the 'taint' of biological determinism in favour of focusing on how concepts of bodies are socially and culturally constructed (cf Alaimo and Hekman, 2002). However, as Lynda Birke argues, since bodies 'become categorised through the language of biomedicine', biology should be taken 'more seriously' (Birke, 1999: 20); 
and several scholars point to the inseparability of the discursive and the material (Barad, 2007; Butler, 1993; Grosz, 1994), emphasizing that

'different procedures of corporeal inscription do not simply adorn or add to a body that is basically given through biology; they help constitute the very biological organization of the subject' (Grosz, 1994: 142).

One way of taking bodies seriously without succumbing to either radical constructionism or determinism is to analyse how bodies are made, that is, shaped and known. Diets (e.g. Popenoe, 2004) and plastic surgery (e.g. Brush, 1998; Kaw, 1993), for example, quite tangibly shape material - as well as gendered, racialized and classed, to name but a few - bodies. To use Judith Butler's terms, the body, and in particular the sexed body, can be seen as a materialization of cultural norms (Butler, 1993: 2). She argues,

'... "sex" is an ideal construct which is forcibly materialized through time. It is not a simple fact or static condition of a body, but a process whereby regulatory norms materialize "sex" and achieve this materialization through a forcible iteration of those norms.' Butler, 1993: 1-2)

Butler posits that it is impossible to separate the material body from cultural norms. Her argument is that the body is a materialization of cultural norms, thus 'to invoke matter is to invoke a sedimented history of sexual hierarchy and sexual erasures' (Butler, 1993: 49). However, Butler's materialization goes further than reshaping already existing bodies into better accordance with cultural norms. Rather, she argues, it is through these norms that bodies are moulded into their material shape.

Karen Barad's framework of agential realism (Barad, 1996, 1998, 2007) is a way of thinking about this inseparability of the material and the sociocultural. Barad argues that it is impossible to separate epistemology and ontology, or the observer and the observed. Instead of an observer gazing at 'nature' (for example bodies) Barad sees an apparatus - consisting of bodies, technologies, norms, ideas - that produces a phenomenon: 'the place where matter and meaning meet' (Barad, 1996: 185). In this, the parts of the apparatus do not pre-exist but are produced during the process, intra-action in Barad's words, a term that draws attention to the inseparability of the parts of the apparatus (Barad, 2007: 132ff). In other words, knowledge, observers, instruments, and observed are enacted and shaped through practices in intra-action, as parts of phenomena. This does not mean that relationships between those forms of agency inevitably have to be symmetrical and harmonious (Barad, 1996: 188). Since, for example, humans 'do the representing' (Barad, 1996: 181), that is, tell the stories about nature, these relationships can and do contain considerable asymmetry. In the case of forensic evidence, it is also humans who decide which forms of materialization are desirable and acceptable. ${ }^{3}$

Consequently, bodies do not exist as a given, but are continuously materialized in 'an iteratively intra-active process whereby material-discursive bodies are sedimented out of the intra-action of multiple material-discursive apparatuses through which these phenomena (bodies) become intelligible' (Barad, 1998: 108; italics in original) ${ }^{4}$

Thinking about bodies in these terms means that it is impossible to separate bodies into a material template and its sociocultural (or discursive) inscriptions - they are one and the same. It also 
implies a different relationship between material bodies and society. Rather than regarding biological bodies as a justification for social order and norms, these norms then are part of materializing the very bodies that are used to justify them.

Bodies in criminal justice are also both material and sociocultural at the same time. They leave behind traces which can be used by law enforcement and the courts to determine who has committed a particular crime, but, contrary to popular portrayals, ${ }^{5}$ traces at crime scenes do not speak for themselves. In order to be usable as evidence with which to achieve criminal convictions, these traces have to be processed in a number of different ways through specific specializations, competencies, and practices. Thus, forensic evidence can be understood as a phenomenon in Barad's sense of the term. It is produced by an apparatus that involves traces, bodies (and not only criminal ones), forensic technologies and practices, law and legal practices, as well as less specialized cultural understandings. Instead of speaking about the body's materiality, it appears more appropriate to speak about its materialization. In her words,

'materialization is not only a matter of how discourse comes to matter but also of how matter comes to matter' (Barad, 1998: 108).

It is thus through the (forensic) apparatus that forensic evidence is produced and, thus, bodies are materialized. I shall now look at my ethnographic material from the Swedish judicial system through the lens of these feminist theories of materialization.

\section{Producing forensic evidence: A chain of transformations}

In Sweden, the path which traces follow through the judicial system is called 'the legal chain', evoking (perhaps unintentionally) associations of a cast-iron linkage between crime scene and conviction. This legal chain, in its ideal form, begins with a police patrol arriving at the scene of the reported crime, and it ends with the final verdict. In everyday practice, there are variations to this model. Not all crime reports lead to a criminal investigation, some investigations never lead to an indictment, and not all verdicts are appealed against. In addition, the involved actors may vary with the crime; for example, in serious crimes, the crime scene is examined by specialized crime scene officers, whereas this task may be performed by a police patrol in common crimes, so-called volume crimes. This article will not discuss details of these variations but will focus on forensic evidence under ideal circumstances, that is, 'successful' materializations.

What is typically emphasized about the legal chain is the linkage between 'the first police officer on the spot' and 'the final verdict', a bond that, on closer inspection, is made up by a number of links or agents. As traces from crime scenes are moved through this chain, they undergo multiple transformations. The crime scene is reduced to traces, whose matter then is transformed into information. This information is compared to other information, and the result reported in standardized expert statements - the forensic evidence. Together with other pieces of evidence, for 
example witness accounts, this evidence is then fashioned into narratives about a course of events and translated into legal categories of culpability.

These transformations are accomplished by an apparatus of actors, instruments, and understandings that produce the phenomenon of forensic evidence and thus actively materialize (criminal) bodies as well as crimes, establishing rather than discovering the connection between a particular body and a particular crime. The following analysis will focus on the chain of transformations for fingerprint and DNA evidence. Both are widely known and practised technologies and, more importantly, both are used to connect particular bodies to particular crime scenes.

\section{Traces}

The first step of producing forensic evidence is to find and collect relevant and promising traces from the crime scene. This assumes that there are traces to be found and collected, however, traces that can be turned into evidence are not a matter of course. Criminals can (and often do) wear gloves, which prevent leaving fingerprints; not everyone's touch leaves equally distinct traces; nor do all surfaces receive and retain fingerprints, and sufficiently clear fingerprints at that, equally well. Conversely, traces that contain DNA are not rare. Expelling tiny droplets of saliva when speaking, or shedding skin cells leave traces that contain DNA. The difficulty is finding these traces and avoiding their contamination with other DNA.

In order to work reasonably efficiently, the crime scene officers must assess which surfaces or objects are likely to carry and retain traces from the crime, and ideally only from the crime. Finding these traces is not always easy, as they often are invisible to the unaided eye; technologies such as ultraviolet light which causes body fluids (which typically contain a lot of DNA) to fluoresce or fingerprint powders are an integral part of crime scene examinations.

The traces do not only have to be left and found to become evidence, they also have to be collected in a way that renders them analysable: fingerprints must not be smudged or obscured, body fluids must not be contaminated. ${ }^{6}$ The collected traces must also be documented and packaged in a way that allows them to be transported to the laboratory without putting them at risk of deterioration, cross-contamination, and mix-ups. This requires skill as well as experience, in addition to the appropriate equipment.

In other words, while traces from a presumptive crime scene may be material traces, it requires human skill, experience, and interpretation as well as technological equipment to find and collect them. They must be actively and correctly entered into the legal chain in order to be able to become evidence. Material bodies both enable producing the phenomenon and offer resistance to it, for example in leaving or not leaving usable fingerprints or threatening contamination. 


\section{Results}

The laboratory analysis ${ }^{7}$ then transforms these traces into information. Apart from laboratory protocols designed to prevent deterioration, contamination, cross-contamination, and mix-ups, this transformation differs between DNA and fingerprint traces. DNA analysis is quite automated - the laboratory routinely handles large numbers of traces, extracting DNA from them and creating profiles of this DNA, a large part of which is done by instruments and computers.

A DNA profile does not contain information from the entire genome; in Sweden, it (currently) contains information from ten so-called loci as well as information about genetic sex. These loci are 'sections' of the genome that are not assumed to code for any proteins, so-called 'junk DNA' without any discernible function in which mutations, and thus genetic diversity, accumulate. This diversity consists of varying numbers of short, repeated sequences. The laboratory can 'measure' the number of these repetitions. As every person inherits each locus twice (one from each parent), such a DNA profile thus consists of a string of 20 figures and a sex marker. ${ }^{8}$ This profile can then easily be stored and compared to other profiles in databases, either from DNA collected from suspects or from other crime scenes.

Fingerprint analysis is much less automated. Specialized fingerprint examiners compare the fingerprints from the crime scene with fingerprints from suspects. They scrutinize enlarged images of the fingerprints on a computer screen, looking for and marking out so-called details in the lines, such as lines that stop or bifurcate. When there is no suspect, the fingerprints from the crime scene are run against the police's fingerprint database, which returns a number of suggestions. These suggestions - or, in the case of a known suspect, their fingerprints - are then manually compared with the fingerprints from the crime scene one by one. ${ }^{9}$ What makes this comparison demanding is, according to the examiners, that fingers are soft and pliable, and thus no two prints made by the same finger are ever exactly identical.

Based on the premise that every fingerprint is unique (see Cole, 2001, 2009 for a critical discussion), in fingerprint evidence a match between a fingerprint from a crime scene and that from a suspect is taken to indicate that the suspect left the fingerprint at the crime scene. A DNA match, however, does, contrary to popular narrative, not mean that the suspect is the only possible source of the trace at the crime scene. As DNA profiles do not cover all genes but only a limited number of loci, there is the - albeit very small - possibility that several individuals might share the same DNA profile. Consequently, a match between two DNA samples is extremely probable when both come from the same source and very unlikely when they do not. Accordingly, the Swedish National Laboratory of Forensic Science, like many international counterparts (see for example Halfon, 1998: 808-811; Lynch et al, 2008: ch 5; M'charek, 2000: 131-135), not only 
reports DNA analysis results as a match (or a mismatch), but also reports how 'valuable' a match is. A full profile match, for example, is reported as 'practically impossible' to obtain if the trace was left by someone else than the suspect, usually termed a random member of the population. ${ }^{10}$ In other words, the laboratory's statement is solely about the analysis result; what the result implies about whether or not the suspect can reasonably be concluded to be the source of the DNA recovered from the crime scene is left for the court to decide. These results are reported in expert statements that move on through the legal chain, that is, to the police and from there to the prosecution, the defence and the courts, where they will be combined with other evidence in the case.

Thus, forensic evidence is not only dependent on procedures of collecting and preserving. Fingerprints or DNA recovered from crime scenes are useless on their own, they require samples from suspects that they can be compared to. These samples are contingent on practices of finding these (potential) suspects. Furthermore, the transformation of traces into information involves different interpretations, made through the intra-action of forensic scientists, instruments, implements, and concepts of human bodies.

\section{Evidence}

An expert statement, however, does not make a conviction. Laboratory results must be assessed, evaluated and, together with the other evidence, transformed into a verdict by the courts. In this, the results' validity itself is usually uncontested in Swedish courts. Both fingerprint and DNA evidence are usually invoked in the form of the laboratory's written expert statement - perhaps at least in part because Sweden does not employ juries, and thus the judges and lay assessors who return the verdict have accumulated a professional attitude to the kinds of forensic evidence that are routinely used. In addition, both prosecution, defence, and court assume that the laboratory has done its job well and produced reliable results.

What is, however, frequently contested and disputed is what the expert statement means for the defendant's culpability in the alleged crime. A fingerprint, for example, may have ended up at the crime scene without connection to the crime; cigarette ends and beverage containers that carry DNA can be planted at a crime scene. Furthermore, what a fingerprint or DNA match can be concluded to confirm is a defendant's presence at a crime scene, not what they were doing there and whether these actions can be categorized as a crime. ${ }^{11}$ Thus, at least in Sweden, forensic evidence by itself cannot bring about a conviction, it needs a context - typically provided by witness and other accounts.

Accordingly, trial proceedings revolve around which conclusions can be drawn or, in legal terms, whether or not the prosecution can prove beyond a reasonable doubt that the defendant is guilty of a particular crime. In this, narratives - from defendants, plaintiffs and witnesses - usually 
make up the main evidence. Forensic evidence is supporting evidence, used as a tool to assess its reliability and thus to strengthen or weaken an account. Both prosecution and defence present their own and contest the other side's versions, offering the court their set of conclusions about the defendant's culpability. In similar fashion to that described by Anthony Amsterdam and Jerome Bruner (2000) for courts in the US, they engage in the telling of stories and counter-stories when presenting their cases. These stories can be very different, drawing on distinct, well-known types of explanations and thus creating different understandings of the defendants' actions. For example, a violent death can be rendered as cold-blooded murder, a madperson's act under hallucinations, a robbery gone wrong, self-defence, or a tragic accident - all of them culturally recognizable understandings with which to attribute meaning to a death. They also have corresponding legal meanings of culpability; madpersons cannot be held responsible for their actions, and killing in self-defence may be lawful, but a cold-blooded murder or a robbery gone wrong are crimes - albeit different ones - for which a defendant will be held responsible.

While legal experts are aware that people do not always behave reasonably or even similarly, notions of how a robber, murderer, or accident victim reasonably ${ }^{12}$ behaves and which conclusions can thus reasonably be drawn are one resource in assessing evidence - after all, the court cannot know what 'really happened', what is put before them is all there is. What makes forensic evidence valuable to the judicial system is not that it can prove culpability - as discussed, it cannot - but that it can be used as a tool with which to assess other evidence in a case and to thus navigate the uncertainty of being unable to know what 'really happened'.

In other words, in order for traces from crime scenes to be transformed into forensic evidence, that is, something that contributes to determining culpability, laboratory results must be interpreted. This implies that forensic laboratory results may not be as immutable as they are popularly described. They do not transport ready-made meaning from the crime scene to the laboratory to the courtroom but are infused with (legal) meaning upon their arrival. It is only through interpretation with the help of both specifically legal, and more general cultural categories and concepts of behaviour, that traces from crime scenes are transformed from laboratory results into forensic evidence.

The transformations that the traces undergo illustrate that the seemingly simple connection between a body at a crime scene and the evidence that can lead to the body's owner being convicted is far from being straightforward. The materiality of fingerprint and DNA evidence is a materiality that is inseparably both material and discursive, made up of intertwined matter and meaning. There is no doubt that matter is an important factor in producing forensic evidence; without bodily traces such as fingerprints or body fluids at crime scenes, there could not be any fingerprint or DNA evidence. However, forensic evidence is far from directly rooted in an immediate bodily materiality. This is not to say that the connection between bodies and evidence is spurious, quite the contrary. The connection is so solid precisely because it is made solid. In this, forensic evidence has intriguing parallels to the sexed bodies discussed by Butler and Grosz: material-discursive practices materialize and solidify bodies or evidence as tangible phenomena. In addition, neither 
sex nor forensic evidence could be meaningful without being (also) discursive.

\section{Materializing bodies and persons}

Analogous to analysing 'what gender does rather than what it is' (Franklin et al, 2000: 7; italics in original), it is useful to ask what forensic evidence does rather than what it is: Its most evident effect is materializing criminal bodies through being used as stand-ins for bodies that are part of criminal persons. Parts of bodies - in forensic science, DNA profiles or fingerprints, in other contexts, body parts, cell counts (see Martin, 1990), chromosomes, or hormones (see Oudshoorn, 1994) - are placed in a synecdochical ${ }^{13}$ relationship as stand-ins for complete bodies. A match with a DNA sample from a crime scene indicates a possibly criminal body whose owner will be asked for an explanation. More than that, the body is materialized in line with the law - through, for example, the definition of which parts of the genome are included into a DNA profile and which are not. The forensic apparatus does not materialize whole bodies through making forensic evidence, but particular bodily constellations - for example, fingerprints or DNA profiles - that are regarded as relevant to solving crimes. A fingerprint or DNA profile becomes a stand-in for a complete body and, in extension, a whole person; it is not an uncommon wording to refer to people (and not their profiles or fingerprints) as being in a database. In other words, persons become matter becomes data (cf Waldby, 2000). Instead of (biological) reductionism of a person to a sexed body, forensic evidence reduces the person to a body that leaves traces. It is the body with its treacherous materiality that can be put under surveillance and that thus can betray the person.

Materializations of bodies are widely connected to very different parts of society. That is, a criminal or sexed (or racialised or classed) body does not become so by virtue of a laboratory result alone, but by the meanings intertwined with it. For example, a chromosome test materializes not only the chromosome itself, but simultaneously a sexed (or ambiguous) person; a fingerprint match may materialize a suspect. Both can with Butler be called 'forcibly materialized' through 'highly regulated practices' (Butler, 1993: 1). In this, both materializations bring about repercussions for the respective bodies' inhabitants, mandating, instigating, inhibiting, or prohibiting actions and, with them, particular subject positions.

\section{Co-materializations}

Producing forensic evidence does not only materialize criminal bodies, however. At the same time, the forensic apparatus also materializes the crime and, with it, the victim. In accordance with the 
presumption of innocence - a suspect or defendant is considered innocent until proven guilty -, an action cannot be called a crime before a conviction; and without a crime, there cannot be a victim. This does not mean, of course, that not yet convicted (or, for that part, acquitted) suspects never are called criminals or that people cannot feel like crime victims without someone being convicted. However, legally, an action is not a crime until and unless a court has pronounced a conviction. Hence, there can be no legal repercussions, such as a sentence for the offender or damages paid to the victim, without a conviction. Thus, a crime is materialized alongside a criminal body ${ }^{14}$ through an apparatus of technology, technoscientific and legal practices as well as other sociocultural practices of creating meaning.

This materialization is, of course, not always successful. It may be impossible to recover or analyse traces, the evidence that is produced may be deemed by the court to allow for reasonable doubt, or the police investigation may lead to the conclusion that, contrary to first impressions, no crime has been committed. Failure to materialize does not, however, mean that the legal system malfunctions; on the contrary, the possibility of failure is an essential part of the legal system. After all, a legal system that equates suspicion with conviction, thereby eliminating the requirement of evidence and its examination by the courts, would not make for a very just criminal justice.

The forensic apparatus has effects that spread beyond the immediate case, as well. Wider organized practices of accumulating fingerprints and DNA-profiles in databases also create a mass of potentially criminal bodies when convicts' fingerprints and DNA-profiles are stored in databases and suspects' DNA-profiles are run against DNA traces recovered from other crime scenes. These digitalized and fragmented bodies are thus part of a larger biopolitical apparatus of a form of governmental surveillance of fluid populations based on the material-semiotics of DNA databases (for example, Braidotti et al, 2009).

Discussions of such biopolitics, inspired by Michel Foucault's conceptualization, often draw attention to the imbalance of power between the state and the individual - whose body, furthermore, may be made to betray her or him to the state. When it comes to forensic evidence, especially DNA evidence, there is considerable concern that this imbalance leads to social inequalities being reinforced as already marginalized groups may be subject to power to a larger extent than others (Duster, 2006). There are also concerns about loss of (genetic) privacy (Dahl and Sætnan, 2009; Noble, 2006; Rothstein and Talbott, 2006), for example in the possibility of socalled familial searches, that is, searching DNA databases for profiles that, as partial matches, indicate a genetic relationship to the DNA found at a crime scene. ${ }^{15}$ In this way, surveillance can be extended to persons outside of the database - and the stored DNA-profiles be made to stand in for an even wider bodily materiality, creating more potential criminal bodies.

That DNA profiles can very easily be stored in databases and thus accessed and compared automatically (on a scale that is currently not possible with, for example, fingerprints), augments the imbalance between the person and the state. In other words, bodies forensically materialized as fragmented entities where the part stands for the whole, can be part of what Nikolas Rose and Carlos Novas have theorized as 'biological citizenship', that is, conceptualizing citizens in biological 
terms (Rose and Novas, 2005, see further Åsberg and Lum, 2009). These biopolitics have advantages as well as disadvantages, such as contributing to solving crimes on the one hand and reinforcing inequalities on the other, issues that must be (and are) discussed.

Still, forensic evidence, with the concerns and expectations it arouses, also points to society's giving precedence to matter over meaning. However, this understanding of forensic evidence neglects and underestimates its discursive dimension and with it the mutability of meaning of, for example, the expert statements that are transformed into this evidence. Regarding forensic evidence as solidly rooted in matter may lead to overconfidence in its immutability and its ability to provide impartial and certain knowledge. The concerns voiced about forensic evidence are indeed relevant, but it should be as relevant to pay attention to how and through which apparatus forensic evidence is produced, that is, within which judicial and political system and through which practices, and what is co-produced in the process, that is, which bodies, crimes, and societies. For example, kinship may be reduced to genetic kinship at the expense of other forms of affinity. Similarly, treating citizens as a gene pool (Rose and Novas, 2005) may impede or even exclude other understandings.

This is especially salient as forensic evidence, not least through popular fictional television shows, has become part of what Sarah Franklin calls 'the genetic imaginary' (Franklin, 2000: 198), a realm of imagining and thinking about life itself in its genetic articulations. Franklin argues that is impossible to extricate life itself from the stories we tell about it. Thus, the stories we tell about bodies and, in extension, persons through the production and use of forensic evidence are part of the apparatus that produces bodies and personhoods, a forensic imaginary so to speak.

\section{Entanglements}

Apart from the forensic imaginary, the forensic apparatus can also contribute to feminist materialist understandings of bodies. Forensic evidence, taken seriously, points to the inseparable entanglements (cf Barad, 2007) of the material and the discursive in its everyday practices. Thus, analyzing the forensic apparatus can contribute to understandings of the inseparability of, for example, sex and gender.

This contribution is largely indirect. Although DNA evidence materializes sex as essentially an additional distinguishing marker (fingerprints are 'sexless'), sex is determined and may be remarked upon when DNA indicates a different sex than that expected from the type of crime. In this, particular notions of sex and gender are set in relation to each other: DNA evidence materializes genetic sex, not sex through hormones, body parts, or brain structure (cf Åsberg, 2009). This genetic sex seems to be strongly connected to gender in terms of notions that, e.g., violent crimes are predominantly committed by men, who are discursively constructed as carriers 
of particular genetic markers and of less inhibitions in terms of acting violent vis-à-vis others. Such connections between men and certain crimes appear to be taken for granted; thus, unexpected female profiles are explicitly commented on, but not (expected) male ones. It is also interesting to note that these connections appear to be attributed to gender rather than sex. The comments are often accompanied by remarks that more and more women are committing 'masculine' crimes.

The material-discursive parts entangled in 'forensic sex' - genetic markers, understandings of violence, crime and gender, crime statistics, society's understandings and treatment of male and female suspects and offenders - might possibly be disentangled, at least partly. However, when it comes to forensic evidence itself, the material and the discursive are entangled more tightly. DNA evidence (and perhaps in the future also fingerprint evidence) is probabilistic and forensic scientists emphasize that they cannot deliver a definite answer as to whose DNA was found at a crime scene. Whether a match indicates that (for example) a bloodstain at a crime scene was left by a suspect and whether this, furthermore, has implications for her or his culpability, is consciously left for the court to decide. Forensic science, by calculating probabilities, delivers only a base for the court's decision.

In other words, a close look at the forensic apparatus makes it transparent how matter and meaning together produce a tangible, solid phenomenon such as forensic evidence. The traces' path from crime scenes through the legal chain, where the phenomenon is produced gradually and in different places with different parts of the apparatus, makes it possible to see the entanglements that materialize forensic evidence as both material and discursive, outside the reach of the nature/culture dichotomy (cf Åsberg, 2009). In similar, although perhaps not as ordered and transparent fashion, it should be possible to track how sex and sexed bodies are produced as inextricably material-discursive.

\section{Conclusions}

I have argued that, rather than granting access to a purely material world, the forensic apparatus materializes forensic evidence which in turn materializes bodies and persons, both by standing in for particular bodies and by contributing to the forensic imaginary. In other words, the making and maintaining of material-discursives is an ongoing, active process, oscillating between entities and 'bits of life' (cf Smelik and Lykke, 2008). Thus, discussions of materialities should rather be discussions of materializations, and materiality should be considered an activity rather than a quality. With the help of Barad's agential realism, it is possible to discuss the inseparability of matter and meaning, culture and nature, or mind and body without evoking determinism. On the contrary, abandoning a presupposed dichotomy of the material and the cultural and instead examining in which ways they, together with technology, materialize into - for example - forensic evidence, 
makes it possible to understand materialities, their production, and, consequently, their role in society without surrendering to either cultural or biological determinism.

This also suggests an expanded view of bodies as inseparably material-technoscientificcultural - they can include a laboratory across the country or the globe, as well as cultural understandings about genes, bodies, and personhood and how they are related. Not only are material(ized) bodies materialized through fragments that are made to represent a whole - for example, as criminal bodies through DNA evidence or as sexed bodies through chromosomes, body parts, or hormones - but they are also materialized as inseparably material, technological, and cultural phenomena in a particular society by an extensive and intricate apparatus. It will be relevant to analyse everyday material-technoscientific-cultural practices of materializing, for example sexed, classed, or racialised bodies, in order to understand both the concrete apparati that materialize these bodies and the phenomena that they co-materialize. I hope that the approach I have explored here that merges feminist materialist theoretizations of bodies, in particular, Karen Barad's agential realism, with an STS-informed analysis of technoscientific practices in crime investigation can inspire further work along these lines. 


\section{References}

Alaimo, Stacy and Susan Hekman (2008) 'Introduction: Emerging Models of Materiality in Feminist Theory', pp 1-19 in S. Alaimo and S. Hekman (eds) Material Feminisms. Bloomington: Indiana University Press.

Amsterdam, Anthony G. and Jerome Bruner (2000) Minding the Law. Cambridge: Harvard University Press.

Åsberg, Cecilia (2009) 'The arena of the body: the Cyborg and feminist views on biology', pp24-38 in R. Buikema and I. van der Tuin (eds) Doing Gender in Media, Art and Culture. London: Routledge.

Åsberg, Cecilia and Jennifer Lum (2009) 'PharmAD-ventures: A Feminist Analysis of the Pharmacological Imaginary of Alzheimer's Disease', Body \& Society 15(4): 95-117.

Bal, Roland (2005) 'How to Kill with a Ballpoint: Credibility in Dutch Forensic Science', Science, Technology, \& Human Values 30(1): 52-75.

Barad, Karen(1996) 'Meeting the Universe Halfway - Realism and Social Constructivism without Contradiction', pp. 161-194 in L. H. Nelson and J. Nelson (eds) Feminism, Science and the Philosophy of Science. London: Kluwer Academical Publishers.

Barad, Karen(1998) 'Getting Real: Technoscientific Practices and the Materialization of Reality',in Differences - A Journal of Feminist Cultural Studies 10(2): 87-128.

Barad, Karen(2007) Meeting the Universe Halfway - quantum physics and the entanglement of matter and meaning. Durham: Duke University Press.

Birke, Lynda (1999) Feminism and the Biological Body. Edinburgh: Edinburgh University Press.

Braidotti, Rosi, Claire Colebrook and Patrik Hanafin (2009) 'Introduction: Deleuze and Law Forensic Futures', pp 1-5 in R. Braidotti, C. Colebrook and P. Hanafin (eds) Deleuze and Law: Forensic Futures. New York: Palgrave Macmillan.

Brush, Pippa (1998) 'Metaphors of Inscription: Discipline, Plasticity and the Rhetoric of Choice', 
Feminist Review 58: 22-43

Butler, Judith (1993) Bodies that Matter. London: Routledge.

Cole, Simon A. (2001) Suspect Identities - A History of Fingerprinting and Criminal Identification. Cambridge: Harvard University Press.

Cole, Simon A. (2009) 'Forensics without uniqueness, conclusions without individualization: the new epistemology of forensic identification', Law, Probability and Risk 8: 233-255.

Dahl, Johanne Yttri and Ann Rudinow Sætnan (2009) '"It all happened so slowly" - On controlling function creep in forensic DNA databases.' International Journal of Law, Crime and Justice 37: 83-103.

Duster, Troy (2006) 'Explaining Differential Trust of DNA Forensic Technology: Grounded Assessment or Inexplicable Paranoia?' Journal of Law, Medicine, and Ethics 34(2): 293-300.

Franklin, Sarah (2000) 'Life Itself - Global Nature and the Genetic Imaginary', pp 188-227 in S. Franklin, C. Lury and J. Stacey (eds) Global Nature, Global Culture. London: Sage Publications.

Franklin, Sarah, Celia Lury and Jackie Stacey (2000) Global Nature, Global Culture. London: Sage Publications.

Gluckman, Max (1963) Order and Rebellion in Tribal Africa - Collected Essays with an autobiographical introduction. London: Cohen \& West.

Grosz, Elizabeth (1994) Volatile Bodies - Toward a Corporeal Feminism. Bloomington: Indiana University Press.

Haack, Susan (2003) 'Trials \& Tribulations: Science in the Courts', Daedalus 132(4): 54-63.

Halfon, Saul (1998) 'Collecting, Testing and Convincing: Forensic DNA Experts in the Courts', Social Studies of Science 28(5-6): 801-821.

Hubbard, Ruth (1990) The Politics of Women’s Biology. New Brunswick: Rutgers University Press.

Jobling, Mark A. and Peter Gill (2004) 'Encoded Evidence: DNA in Forensic Analysis', Nature Reviews Genetics 5: 739-751. 
Kaw, Eugenia (1993) 'Medicalization of Racial Features: Asian American Women and Cosmetic Surgery', Medical Anthropology Quarterly 7(1): 74-89.

Kruse, Corinna (2010) 'Producing Absolute Truth: CSI Science as Wishful Thinking', American Anthropologist 112(1): 79-91.

Littlefield, Melissa (2009) 'Constructing the Organ of Deceit: The Rhetoric of fMRI and Brain Fingerprinting in Post-9/11 America', Science Technology, \& Human Values 34(3): 365-392.

Lynch, Michael, Simon A. Cole, Ruth McNally and Kathleen Jordan (2008) Truth Machine - The Contentious History of DNA Fingerprinting. Chicago: The University of Chicago Press.

M'charek, Amâde (2000) 'Technologies of Population: Forensic DNA Testing Practices and the Making of Differences and Similarities', Configurations 8: 121-158.

Martin, Emily (1990) ‘The End of the Body?’ American Ethnologist 19(1): 121-140.

McCartney, Carole (2006) Forensic Identification and Criminal Justice - Forensic science, justice and risk. Portland: Willan Publishing.

Noble, Alice A (2006) 'DNA Fingerprinting and Civil Liberties', Journal of Law, Medicine, and Ethics 34(2): 149-152.

Oudshoorn, Nelly (1994) Beyond the Natural Body - An archeology of sex hormones. London: Routledge.

Popenoe, Rebecca (2004) Feeding desire - fatness, beauty, and sexuality among a Saharan people. London: Routledge.

Prainsack, Barbara and Martin Kitzberger (2009) 'DNA Behind Bars - "Other” Ways of Knowing Forensic DNA Technologies', Social Studies of Science 39(1): 51-79.

Rose, Nikolas and Carlos Novas (2005) ' Biological Citizenship', pp 439-463 in A. Ong and S. J. Collier (eds) Global Assemblages - Technology, Politics, and Ethics as Anthropological Problems. Malden: Blackwell Publishing.

Rothstein, Mark A. and Meghan K. Talbott (2006) 'The Expanding Use of DNA in Law Enforcement: What Role for Privacy?' Journal of Law, Medicine, and Ethics 34(2): 153-164. 
Smelik, Anneke and Nina Lykke (2008) 'Bits of Life - An Introduction', pp ix-xix in A. Smelik and N. Lykke (eds) Bits of Life - Feminism at the Intersections of Media, Bioscience, and Technology. Seattle: University of Washington Press.

Waldby, Catherine (2000) 'The visible Human Project - Data into flesh, flesh into data', pp 24-38 in J. Marchessault and K. Sawchuck (eds) Wild Science - Reading Feminsm, Medicine and the Media. London: Routledge.

Watson, James D., Richard M. Myers, Amy A. Caudy and Jan A. Witkowski (2007) Recombinant DNA: Genes and Genomes - A Short Course. New York: W. H. Freeman and Company. 
1 I am grateful to my collaborators within the Swedish judicial system who graciously opened their world to me and generously made time for me in their strained schedules. I am also grateful to Cecilia Åsberg and Nina Lykke for perceptive and constructive criticism, to Katherine Harrison for helping and asking difficult questions, and to the anonymous reviewers for their insightful comments. And I would like to thank Ericka Johnson for luring me into feminist materialism.

2 I use 'producing', as it draws attention to the agency involved in making forensic evidence without connoting fabrication.

3 See Littlefield (2009) for discussions of a (currently) less accepted technology of materialization of crime.

4 The 'bodies' Barad refers to are not necessarily human or even biological bodies.

5 For a discussion of one of them, see Kruse (2010).

6 It is also possible to collect portable objects that (may) carry traces and send them to the laboratory as a whole. However, this will only delegate the task to a more specialized actor, the task itself remains the same.

7 In Sweden, all DNA analyses and complicated fingerprint analyses are performed by the Swedish National Laboratory of Forensic Science.

8 See Watson et al. (2007: chapter 16) for an overview of DNA profiling; see Jobling and Gill (2004) for a detailed discussion.

9 This also means that while it is theoretically possible to transform each and every fingerprint from, for example, an apartment, into evidence, the sheer amount of work needed to process such a quantity of fingerprints makes it an infeasible task.

10 'Population' can be a contested concept in this context; see M'charek 2000 (131-135).

11 There are cases and circumstances when forensic evidence can shed light on activities - for example in bloodstain analysis - but it still must be translated into legal categories.

12 An allusion to Max Gluckman. From his fieldwork in then Northern Rhodesia, Gluckman concluded that jurisprudence contrasts behaviour and accounts against 'standards of how a reasonable man would behave' (Gluckman, 1963: 184), standards that are specific to situation and, presumably, culture.

13 A synecdoche is a figure of speech that uses a part to refer to a whole, or vice versa.

14 Forensic evidence is, however, not the only means of determining that an action is a crime; it is entirely possible to convict someone on witness testimonies.

15 Not all countries allow familial searches. 